\title{
Havemos de ser atendidos em nossos direitos, uma vez que servimos para votantes e soldados, não obstante a nossa cor: associativismo negro, direitos e cidadania (a Sociedade Beneficente Cultural Floresta Aurora, Porto Alegre, séc. XIX)
}

We must be respected in our rights, as we serve voters and soldiers regardless of our color: black associations, rights and citizenship (The Floresta Aurora Cultural Charity Society, Porto Alegre, 19th century)

\section{Paulo Roberto Staudt Moreira*}

Resumo: Tomando a noção de racialização como o gerenciamento cotidiano, político e identitário dos pertencimentos étnico-raciais, pretendemos analisar o associativismo negro, ainda no período escravista, através da Sociedade Beneficente Cultural Floresta Aurora. Essa entidade foi criada na cidade de Porto Alegre, capital da província de São Pedro do Rio Grande do Sul, em 1872, e ainda não conhecemos detalhadamente os seus integrantes. Portanto, o artigo almeja verticalizar o estudo dessa associação montando pequenas trajetórias de alguns de seus promotores e, através de um documento judiciário, especular sobre as motivações desses jovens negros para o investimento nessa forma de representação coletiva. Ao acessar a justiça pedindo reparação das ofensas recebidas, os músicos negros da Floresta Aurora nos ajudam a pensar a agenda de suas reivindicações políticas e morais.

Palavras-chave: associativismo negro; direitos; cidadania.

\begin{abstract}
Taking the notion of racialization as the daily political and identity management of ethnic-racial belongings, we intend to analyze black associativism, even in the slave period, through the Sociedade Beneficente Cultural Floresta Aurora. This entity was created in the city of Porto Alegre, capital of the province of São Pedro do Rio Grande do Sul, in 1872, and we do not know its members in detail yet. Therefore, the article aims to verticalize the study of this association by setting short trajectories of some of its promoters and, through a judicial document, speculate on the motivations of these young blacks to invest in this form of collective representation. By accessing justice asking for reparation for the offenses received, the Aurora Forest black musicians help us think through the agenda of their political and moral claims.
\end{abstract}

Keywords: black associativism; rights; citizenship.

* Doutor em História - UFRGS, professor titular da Universidade do Vale do Rio dos Sinos UNISINOS, bolsista de Produtividade em Pesquisa do CNPq - Nível 2. E-mail: moreirast@terra. com.br. ORCID: https://orcid.org/0000-0003-1286-2874. 


\section{"Mais antiga que a própria liberdade de seu povo": a Floresta Aurora}

Em seu livro Gerações de cativeiro: uma história da escravidão nos Estados Unidos, publicado originalmente em 2003, o historiador Ira Berlin conta que, na segunda metade do século XIX, sentia-se, com mais densidade ainda, "o mau cheiro moral da escravidão". Assumindo uma agenda de pesquisa que influenciou muitos historiadores a partir dos anos 1990, Berlin destaca que "a liberdade, como a escravidão, não estava definida, sendo constantemente reelaborada". Afinal:

A experimentação da nova liberdade perturbava as relações entre os libertos e os homens que os tinham conhecido apenas como escravos. Antigos senhores não aceitavam as novas circunstâncias, interpretando as atitudes dos libertos como ingratidão e insolência. Brancos pobres também se sentiam ultrajados, pois a distância entre eles e os ex-escravos se reduzia a nada mais que sua pele branca. $^{1}$

Ou seja, é preciso reafirmar que o destino, o papel e o lugar social (e político) dos egressos do cativeiro estava sendo debatido e gerenciado bem antes da promulgação da Lei Áurea. Nessa perspectiva, tomando a noção de racialização como o gerenciamento cotidiano, político e identitário dos pertencimentos étnicoraciais, pretendemos analisar o associativismo negro, ainda no período escravista, através da Sociedade Beneficente Cultural Floresta Aurora. ${ }^{2}$ Essa entidade foi criada na cidade de Porto Alegre, capital da província de São Pedro do Rio Grande do Sul, em 1872, e ainda não conhecemos com mais detalhes os seus integrantes. Portanto, o artigo almeja verticalizar o estudo dessa associação montando pequenas trajetórias de alguns de seus promotores e, através de um documento judiciário, especular sobre as motivações desses jovens negros para o investimento nessa

BERLIN, Ira. Gerações de cativeiro. Uma história da escravidão nos Estados Unidos. São Paulo: Editora Record, 2006. p. 14, 15 e 310.

2 Sobre racialização, ver: ALBUQUERQUE, Wlamyra. A vala comum da 'raça emancipada': abolição e racialização no Brasil, breve comentário. História Social, n. 19, segundo semestre de 2010. ALBUQUERQUE, Wlamyra. O jogo da dissimulação: abolição e cidadania negra no Brasil. São Paulo: Companhia das Letras, 2009. FASSIN, Didier. Nem raça, nem racismo: o que racializar significa. In: SCHWARCZ, Lilia M.; MACHADO, Maria Helena P. T. Emancipação, inclusão e exclusão: desafios do passado e do presente. São Paulo: Editora da Universidade de São Paulo, 2018. FISCHER, Brodwyn; GRINBERG, Keila; MATTOS, Hebe. Direito, silêncio e racialização das desigualdades na história afro-brasileira. In: ANDREWS, George Reid; La FUENTE, Alejandro de. Estudos afro-latino-americanos: uma introdução. Buenos Aires: CLACSO, 2018, p. 163-215. ANDREWS, George Reid. Desigualdade: raça, classe e gênero. In: Ibidem. WEIMER, Rodrigo de Azevedo. Felisberta e sua gente: consciência histórica e racialização em uma família negra no pós-emancipação rio-grandense. Rio de Janeiro: Editora FGV, 2015. SILVA, Fernanda Oliveira da. As lutas políticas nos clubes negros: culturas negras, racialização e cidadania na fronteira BrasilUruguai no pós-abolição (1870-1960). 2017. Tese (Doutorado em História) - Universidade Federal do Rio Grande do Sul, Porto Alegre, 2017. 
forma de representação coletiva. Ao acessar a justiça pedindo reparação das ofensas recebidas, os músicos negros da Floresta Aurora nos ajudam a pensar a agenda de suas reivindicações políticas e morais.

O caso de violência física que acessamos através dos indícios deixados em um não muito extenso documento judiciário ocorreu no início da década de 1880 . No Rio Grande do Sul e no restante do Brasil:

\begin{abstract}
Este período foi marcado pela preocupação acerca do destino dos libertos; pelo debate acerca da concessão de direitos civis àqueles que, até então, eram não cidadãos; pela incidência de diversas medidas de controle social sobre os trabalhadores; e pela busca de soluções para a suposta "ausência de mão de obra" gerada pelo cada vez mais elevado número de alforrias, problemas que, segundo muitos administradores públicos e jornalistas, deveriam ser resolvidos através da importação de trabalhadores europeus, que serviriam também para tornar produtivas as terras "vazias" do Rio Grande do Sul e guarnecer as fronteiras provinciais diante das repúblicas platinas. ${ }^{3}$
\end{abstract}

\title{
"Não lhe tenho dito que não venda cerveja a esta gente?"
}

O conflito que iremos tratar ocorreu em um domingo da Ressurreição, dia importante do calendário católico, quando se celebra o momento em que Jesus volta à vida, no domingo seguinte à Sexta-feira da Paixão, quando foi crucificado no calvário. Narra a Bíblia Sagrada "que Cristo morreu por nossos pecados [...] E que foi sepultado, e que ressuscitou ao terceiro dia [...] E que foi visto por Cefas, e depois, pelos doze. Depois foi visto, uma vez, por mais de quinhentos irmãos, dos quais vive ainda a maior parte, mas alguns já dormem também. Depois foi visto por Tiago; depois, por todos os apóstolos". Se a Sexta-feira Santa é momento de reflexão e introspecção, no domingo se sugere alegria e festa, pois o ato da ressurreição confirma a fé cristã. Segundo o apóstolo Paulo: "E, se Cristo não ressuscitou, é, pois, vã a nossa pregação, é também vã a nossa fé, e somos assim considerados falsas testemunhas de Deus". ${ }^{4}$

Talvez pela expectativa de que demonstrações de alegria e júbilo estivessem presentes naquele dia santo, que anunciava a reafirmação da ressureição de Cristo e, portanto, da fé cristã, alguns músicos da Sociedade Beneficente Cultural Floresta Aurora compareceram ao cemitério de Porto Alegre, no domingo de 28 de março de 1880. Fruto de demandas higienistas da primeira metade do século XIX, a nova necrópole de Porto Alegre foi instalada no Alto da Azenha, sob a administração da Santa Casa de Misericórdia de Porto Alegre, em 1850, e substituiu o campo santo

3 ROSA, Marcus Vinícius de Freitas. Além da invisibilidade: história social do racismo em Porto Alegre (1884-1918). 2014. Tese (Doutorado em História) - Universidade Estadual de Campinas, Campinas, 2014. p. 2.

4 BíBlIA SAGRADA. 19a edição. São Paulo: Edições Paulinas, 1965. p. 1387 (Coríntios 15). 
anterior, que se localizava no centro da capital, ao lado da catedral da Madre de Deus. ${ }^{5}$

Mas nem todos os moradores de Porto Alegre estavam imbuídos dos fraternais fluidos daquele domingo festivo. Ao descerem do Alto da Azenha, os músicos negros da Floresta Aurora, talvez ambicionando manter a essência religiosa daquele dia, foram se espiritualizar em uma venda localizada no Campo do Bom Fim. ${ }^{6}$ Lá ocorreu um conflito bastante violento, que gerou uma queixa para as autoridades feita quatro dias depois, numa quinta-feira, $1^{\circ}$ de abril de $1880 .^{7}$

O queixoso foi o carpinteiro Eduardo José Ferreira, um dos músicos da Floresta Aurora, mas o ofício da queixa dirigida ao juiz de Direito do $2^{\circ}$ Distrito Criminal de Porto Alegre, Miguel Antônio Dutra Filho, foi redigido por outra pessoa, Marcos Menezes Correia de Castro. Não se tratou de uma delegação de escrita, já que Eduardo era alfabetizado, mas naquele momento ele ainda estava impossibilitado de escrever e mesmo de assinar "por estar com o braço doente" da agressão sofrida no domingo da Ressurreição.

Ao fazer sua queixa, mesmo que por intermédio de outrem, Eduardo apresenta-se com a profissão de carpinteiro, nascido em Porto Alegre, onde morava ainda, tinha 28 anos de idade, solteiro, alfabetizado. Sua queixa é dirigida contra Antônio Marcos Alves Pereira, morador na Azenha, esquina do Campo do Bom Fim, onde era estabelecido com uma taberna. Diz a queixa:

No dia 28 de março deste ano, vindo o queixoso do cemitério pelas 10 horas da manhã, com as testemunhas abaixo arroladas, entrou na taberna do acusado para tomar um copo de cerveja e aí foi servido pelo caixeiro da casa, aparecendo depois o acusado que estava ausente, maltratou o caixeiro por ter servido ao queixoso, que lhe disse que não havia razão para tal procedimento; o acusado dirigindo muitos insultos ao queixoso o feriu com um peso de 500 gramas, o qual foi pelo queixoso entregue ao delegado de polícia [...] sendo preciso que o queixoso se retirasse para mais não sofrer.

5 NASCIMENTO, Mara Regina do. As irmandades no meio urbano: práticas funerárias e religiosidade entre os leigos. Porto Alegre (1780-1850). 2004. Tese (Doutorado em História) Universidade Federal do Rio Grande do Sul, Porto Alegre, 2004. MEIRELLES, Pedro von Mengden. Um terreno cheio de asperezas: o Cemitério da Matriz de Porto Alegre no cotidiano da cidade (1772-1888). Dissertação (Mestrado em História) - Universidade Federal do Rio Grande do Sul/ PPGH, Porto Alegre, 2016.

6 O Campo do Bom Fim recebeu essa denominação em função da construção da capela dessa devoção que, apesar de ficar pronta apenas em 1883, desde 1870 o local era assim chamado. Aliás, a denominação mudou já no ano seguinte, quando a campanha abolicionista criou a ficção de que Porto Alegre estava redenta da mácula da escravidão e aquele território passou a ser chamado, oficialmente, de Campo da Redenção. Em 1935, por ocasião da comemoração do centenário da guerra civil (1835-1845), o parque passou a ser chamado de Farroupilha, mas como Redenção ainda é conhecido pelo gosto popular.

7 APERS - Juízo de Direito do $2^{\circ}$ Distrito Criminal de Porto Alegre, Sumário, auto 1401, maço 53. Autor: Eduardo José Ferreira. Réu: Antônio Marcos Alves Pereira. 
O músico-carpinteiro Eduardo pediu que o agressor fosse incurso na seção IV do Código Criminal de 1830, que se referia a ferimentos e outras ofensas físicas, especificamente em seu artigo 201 ("Ferir ou cortar qualquer parte do corpo humano, ou fazer qualquer outra offensa physica, com que se cause dôr ao offendido"), que determinava pena de prisão por um mês a um ano e "multa correspondente a metade do tempo". Contando as circunstâncias agravantes abaixo, do mesmo código, no seu artigo 16:

$4^{\circ}$ Ter sido o delinquente impellido por um motivo reprovado, ou frivolo.

$6^{\circ}$ Haver no delinquente superioridade em sexo, forças, ou armas, de maneira que o offendido não pudesse defender-se com probabilidade de repellir a offensa.

10. Ter o delinquente commettido o crime com abuso da confiança nelle posta.

15. Ter sido o crime commettido com surpresa.

Conforme expressado no trecho da queixa citado acima, as cinco testemunhas arroladas pelo queixoso para embasar a sua reclamação na justiça eram seus companheiros de música e associativismo, que o acompanhavam naquele domingo santo. Eram eles: Isidoro Francisco Xavier, Paulo Baptista [da Silva], Ataliba de Castro, Jacinto José Bonifácio e Teodoro Augusto Ferreira.

Se a queixa foi feita só na quinta-feira, no mesmo dia da agressão o ofendido, mostrando conhecimento dos trâmites burocráticos exigidos, recorreu ao delegado de polícia João Pereira Maciel, pedindo que fosse realizado um auto de corpo de delito nele mesmo, comprovando os ferimentos recebidos. O exame ocorreu na segunda-feira, 29 de março, e dele se encarregaram os doutores em medicina Raimundo Caetano da Cunha e Manoel Martins dos Santos Penna, tudo testemunhado por dois indivíduos (Manoel Correia de Oliveira Figueiredo e João Antônio de Oliveira). Os médicos encontraram uma:

[...] ferida contusa na região fronto-parietal direita, no sentido oblíquo, de cima para baixo, de diante para trás, ofendendo ao couro cabeludo na extensão de dois centímetros; uma ferida contusa no terço médio do antebraço direito, face externa, de um centímetro de extensão.

Os facultativos consideraram que os ferimentos foram causados por um instrumento contundente e que não causavam risco de vida ao ofendido nem grave incômodo de saúde, e seria curável em 15 dias. No auto de qualificação, o réu Antônio Marcos Alves Pereira apresenta-se como filho de José Alves Pereira, com 28 anos de idade, português, nascido na cidade da Guarda, solteiro, negociante e alfabetizado, e que residia na Azenha há dois anos mais ou menos. 


\section{PAULO ROBERTO STAUDT MOREIRA}

A primeira testemunha a depor foi o pedreiro Ataliba de Castro, com 23 anos, solteiro, morador no centro de Porto Alegre, na rua dos Andradas, analfabeto. Ele contou para a justiça que no domingo da Ressurreição desceu do cemitério "para esta cidade", por volta das 10 horas da manhã, na companhia de Isidoro Francisco Xavier, Paulo Baptista, Teodoro Augusto Ferreira e Jacinto José Bonifácio, entrando o grupo na casa de negócio de "um tal Oliveira, com o fim de tomarem cerveja". Nesse estabelecimento encontraram o queixoso Eduardo, e como ali não encontrassem "a cerveja que desejavam", foram, a convite do mesmo, à casa de negócio de Antônio Marcos.

$\mathrm{Na}$ taberna de Antônio Marcos pediram cerveja ao menino que servia de caixeiro, a qual Ihes foi servida. Quando já estavam com a cerveja nos copos, chegou do interior da casa o réu, que reclamou que o menino continuava vendendo aquela bebida a qualquer um e que ele já proibira isso. $O$ menino respondeu que não tinha ouvido esta proibição e o réu, depois de despejar a cerveja no chão, deu- Ihe uma bofetada. O queixoso então perguntou ao réu porque agredira o caixeiro, se a bebida estava paga "e ele o conhecia perfeitamente. A essa pergunta o acusado respondeu-Ihe que não tinha satisfação a dar-Ihe" e atirou o peso, agredindo-o com uma medida.

O pedreiro Ataliba, então, conta que levaram o carpinteiro Eduardo, ferido, para a casa de uma senhora, vizinha da taberna. Além disso, acrescenta que ninguém do grupo, nem mesmo o queixoso que foi ferido, usou qualquer palavra ofensiva que motivasse a agressão e que o queixoso não estava armado. Aliás, ele declarou que conhecia o queixoso Eduardo "há algum tempo e não lhe consta que seja homem de maus costumes". Já o réu, a testemunha viu-o naquele dia pela primeira vez, mas ouviu dizer que ele tem costume de assim proceder. Respondendo a uma provocativa pergunta do réu taberneiro, o pedreiro Ataliba disse que, após a agressão, o acusado fechou a porta de sua casa de negócio e o grupo permaneceu do lado de fora por mais uma ou duas horas, e que ali ficaram por ordem do subdelegado Madeira. Segundo Ataliba, o grupo de músicos estava reunido desde as 8 da manhã daquele domingo, quando acompanharam um enterro até o cemitério, e que o queixoso ia junto, mas voltou antes.

O réu contestou o depoimento da testemunha, dizendo que ela "adultera a verdade dos fatos". A testemunha e seus companheiros, segundo ele, teriam jogado achas de lenha, "resultando-Ihe ferimentos e ficar com os vidros da armação de sua casa de negócio quebrados". Ou seja, a narrativa do taberneiro português era de que os companheiros do ofendido permaneceram reunidos do lado de fora da sua casa de negócio em postura agressiva, talvez premeditando uma vingança. Ataliba manteve a sua declaração e ainda disse que ninguém do grupo agrediu o taberneiro, 
e que se assim o tivessem feito, "sendo tantos contra um", ele necessariamente teria ficado seriamente ferido.

Logo após depôs o sacristão da igreja das Dores, Isidoro Francisco Xavier, com 32 anos de idade, solteiro, morador na rua do Riachuelo, no centro de Porto Alegre, cidade onde nasceu, alfabetizado. A sua narrativa é estruturada da mesma forma de seu companheiro Ataliba de Castro, mas ele acrescenta detalhes significativos, o que parece caracterizá-lo como um indivíduo plenamente consciente do que estava envolvido naquele embate de aparência corriqueira. Segundo ele, o grupo desceu do cemitério para a cidade, parando na casa de Oliveira \& Irmãos, mas ali não havia mais cerveja, que havia sido toda vendida para um baile. Foram então para a venda do réu e, após serem servidos de cerveja, esse apareceu e recriminou o caixeiro que os servira, dizendo: "Não lhe tenho dito que não venda cerveja a esta gente?". Após o caixeiro argumentar que não ouvira essa proibição, o réu então despeja os copos no chão e lhe dá uma bofetada, ao que o queixoso reclamou: "Senhor Antônio, olhe que the conheço, isto não são desfeitas que se façam a homens". O português dirigiu nesse momento ao queixoso palavras obscenas e fez os ferimentos. O sacristão Isidoro conta que o grupo saiu carregando o seu companheiro ferido e que ele testemunha teria dito: "Vamos embora, temos justiça, recorramos a ela; certamente havemos de ser atendidos em nossos direitos por ela, uma vez que servimos para votantes e soldados, não obstante a nossa cor".

A impressão que temos ao lermos o depoimento do sacristão Isidoro Francisco Xavier é que ele politiza o acontecimento, explicitando as conotações raciais que ali estavam envolvidas. A gente a qual o taberneiro português se referia pejorativamente, proibindo o consumo de gêneros e a consequente permanência em sua taberna ou venda, tinha cor; aliás, era exatamente a cor dos integrantes daquele grupo de músicos que o incomodava. Entretanto, percebamos que naquele cenário típico das sociabilidades populares, racismo e masculinidade se cruzavam e se reforçavam mutuamente. Duvidar da capacidade de pagar a bebida consumida, jogar a cerveja ao chão, dar um tapa na cara do caixeiro, são todos itens que envolvem rixas potencialmente muito violentas entre homens. A exclusão racial, assim, era acompanhada do estabelecimento de uma masculinidade subalterna, negando-se certos atributos essenciais da afirmação da virilidade. ${ }^{8} \mathrm{O}$ carpinteiro Eduardo enuncia isso quando desaprova as ações do taberneiro dizendo que "isto não são desfeitas que se façam a homens". Aqui parece estar em ação um exercício evidente de afirmação de masculinidade, que se desenrola no espaço público de

8 BANDEIRA, Gustavo Andrada. Um currículo de masculinidades nos estádios de futebol. Revista Brasileira de Educação. v. 15, n. 44, p. 342-410, maio-ago. 2010. 
um bar. ${ }^{9}$ Talvez com essa fala Eduardo tenha ainda procurado uma acomodação da ofensa racial buscando uma solidariedade masculina, mas que não deu certo com aquele vendeiro lusitano.

Como já dissemos, o sacristão Isidoro Francisco Xavier parece ser dos personagens mais hábeis naquele acontecimento de 1880 , nas tratativas de agenciamento da esfera pública. Partiu de sua iniciativa chamar o doutor Raimundo para atender o ofendido e depois fazer o corpo de delito, além de recolher o peso com qual o taberneiro praticou o ferimento, que ficou jogado fora da venda, entregando-o no dia seguinte ao delegado de polícia. Obviamente os personagens compartilhavam sentimentos comuns com relação aos obstáculos que a sua cor carregava, mas eles eram plurais em termos de prestígio social e capacidade de mobilização. A atuação de Isidoro como sacristão certamente teve influência em sua forma criativa de agir e pensar, na sua maneira mais autônoma e desembaraçada de se relacionar com as autoridades e de formatar reivindicações. A atuação no campo religioso deve ter the ampliado as redes e os contatos sociais e as suas responsabilidades como sacristão o habilitaram a resolver pendengas variadas e mesmo lhe dotaram de um vocabulário mais consistente, permitindo-Ihe enunciar demandas individuais e, principalmente, coletivas. A frase que ele insere em seu depoimento, que teria sido dita na saída da casa de negócio, quando aqueles músicos negros carregavam o companheiro ferido (e que usamos de título desse artigo), evidencia uma consciência aguda das esferas de cidadania (serviço militar e eleições) nas quais estavam envolvidos os indivíduos negros (principalmente os livres e libertos), nos oitocentos. A isso voltaremos em breve.

O depoimento do sacristão é preciso ao rebater as críticas do réu e ao desviar-se das insinuações da polícia, manipulando valores rejeitados com mais dificuldade pelas autoridades públicas. $O$ delegado de polícia sempre pergunta às testemunhas se o queixoso estava armado e se proferiu palavras ofensivas, atos que justificassem a agressão sofrida. Complementando seu testemunho, Isidoro consolida o caráter delituoso do réu, dizendo que ele já havia esbordoado outras pessoas, como um Teles, um Barbosa e um Marciano, este último oficial de justiça. Quanto ao queixoso, "sabe que é um homem pacífico, oficial de carpinteiro e que com seu trabalho sustenta a sua mãe", mesclando assim, numa mesma e curta sentença, prestígio socioprofissional (oficial de carpinteiro) e afastando-o de qualquer imagem

Pesquisas focando temporalidades diferentes destacaram a troca e o consumo de bebidas alcoólicas nos bares como uma (re)afirmação da masculinidade entre homens populares: JARDIM, Denise. De bar em bar: identidade masculina e autossegregação entre homens de classes populares. Dissertação (Mestrado em Antropologia Social) - Universidade Federal do Rio Grande do Sul/PPGAS, Porto Alegre, 1992. MOREIRA, Paulo. Entre o deboche e a rapina: os cenários sociais da criminalidade popular (Porto Alegre - século XIX). Porto Alegre: Armazém Digital, 2009. 
de anomia social (afinal, ampara a mãe). O grupo permaneceu na casa de uma senhora, vizinha do agressor, até que um carro chegasse para levar o ofendido, indo alguns deles junto na condução e outros a pé para a cidade. Ao final, o réu contestou o depoimento, mas o sacristão não lhe deixou com a última palavra, dizendo que ele "seguiu sempre o caminho da verdade", sentença certamente influenciada por seu trânsito na esfera católica.

Em seguida deu seu depoimento o também carpinteiro Paulo Batista da Silva, solteiro, com 25 anos de idade, como os demais natural de Porto Alegre, onde morava na zona central, na rua do Vigário José Inácio (rua em que se localiza a igreja de Nossa Senhora do Rosário). A maioria dos detalhes da narrativa segue o que já haviam dito seus companheiros. Ele esclarece que não havia cerveja na casa de Oliveira \& Irmãos, pois tinham vendido toda ela para um casamento, e que na taberna do réu também encontrava-se "um homem alto, de cor parda, bastante barba, que ele testemunha não conhece". Quando tomavam cerveja, o réu veio do fundo da venda "a palitar os dentes como quem acabava de almoçar e com ares de quem se achava com qualquer alteração de espírito", e ao entornar as cervejas no chão, com o movimento também caiu o dinheiro que estava no balcão, com que o queixoso pagaria as bebidas. Esse detalhe parece importante para a testemunha, pois mostra que o grupo de músicos não queria beber fiado. Segundo Paulo, eles levaram o amigo ensanguentado para a casa de uma senhora, vizinha de Felicíssimo, onde encontraram apenas uma preta doente, uma hora depois é que chegou a dona da casa "a qual lhes disse que se retirassem, visto que era alugada em casa do acusado e este achava-se incomodado por terem eles se abrigado ali”.

Novamente, provocando a testemunha e tentando dar uma versão ao ocorrido que inocentasse o taberneiro português, jogando a culpa ou responsabilidade sobre os músicos negros, o delegado pergunta a Paulo Batista se havendo tantos indivíduos, como nenhum deles interviu na defesa de Eduardo? A testemunha respondeu que ele e outros, como Isidoro Xavier, "aconselhavam que era mais prudente não se envolverem nessa luta e recorrerem à justiça". Quanto ao queixoso, Paulo conta que ele "vive trabalhando, tendo a seu cargo sua mãe, uma irmã e duas crianças menores, a quem sustenta, não lhe constando que jamais tenha praticado ato algum criminoso e nem que tenha se visto envolvido em processo de qualquer natureza". O réu, ao contrário, já tinha se envolvido em várias confusões e o carpinteiro Paulo passou a descrevê-lo com desenvoltura, mostrando-se muito bem informado, talvez contando com informantes dentro da própria secretaria de polícia: 
Há um ano, que se completa amanhã, feriu ele a João Paulino da Silva, dando-lhe com um tinteiro, pelo que foi processado estando o respectivo processo atualmente na secretaria da Delegacia de Polícia; um oficial de justiça de nome Marciano uma vez indo citar o acusado ou falar com ele sobre assuntos inerentes a seu cargo, ponto este que ele testemunha não afirma, foi pelo acusado injuriado, resultando para isto de tal fato, um outro processo que existe parado no cartório do escrivão Guedes; Francisco Medina também, quando o acusado tinha negócio na rua da Margem, foi maltratado por este, o qual atirou-Ihe com uns pratos; há um ano e meio mais ou menos, trabalhando ele testemunha na rua da Olaria, chegou um servente da obra, dizendo que o acusado havia espancado um carroceiro; e, finalmente, no dia em que se deu o fato de que se trata, ainda um homem velho, que se achava no pavimento térreo da casa de Felicíssimo, disse-lhe que o acusado há dias, auxiliado por seus caixeiros, havia esbordoado um homem que de lá saíra a cavalo, cambaleando, sem que houvesse alguém que o socorresse. [grifos nossos]

Outra testemunha a depor, das arroladas pelo próprio queixoso, foi outro carpinteiro. Teodoro Augusto Ferreira tinha 27 anos, era solteiro, analfabeto, natural desta província e morador na rua da Margem, em Porto Alegre. A narrativa segue a mesma direção da de seus companheiros, mas ele acrescenta que o agressor jogou o peso da balança no ofendido duas vezes, que na primeira vez bateu na balança e caiu ao chão, sendo devolvido ao mesmo pelo caixeiro, que daí o jogou na cabeça do carpinteiro Eduardo. Eles levaram o ferido para a casa de uma mulher que mora junto à de Felicíssimo Manoel de Azevedo, "a qual ficou receosa de que o acusado se incomodasse por ter dado agasalho ao queixoso", mas anuiu em que o ofendido ali ficasse enquanto buscavam um médico.

Respondendo à provocação do delegado, que perguntou se o ofendido estava armado, disse que ele trazia consigo apenas um chapéu de sol, pois o dia estava frio e chuvoso, e que era "homem trabalhador, morigerado e sustenta com seu trabalho sua mãe, uma irmã e alguns órfãos". O réu replica que o queixoso e seus companheiros beberam cerveja e aguardente e que ele dissera aos seus caixeiros (havia dois) que não vendessem mais bebidas e que eles se retirassem para não haver mais algazarra. O carpinteiro Teodoro sustentou o seu depoimento, acrescentando que a cerveja jogada fora já estava paga.

A pedido do queixoso, é incluída no processo a parte dada pelo subdelegado do $5^{\circ}$ Distrito Antônio José da Silva Madeira, no dia do conflito. Segundo essa autoridade policial, às 4 horas da tarde daquele domingo da Ressurreição, "uns pretos vindos de um enterro" pediram cerveja e houve um conflito com o dono da venda, ficando ferido um dos pretos e algumas vidraças quebradas. A parte do subdelegado é tão sucinta que nos faz pensar que ele não cogitava que aquele caso fosse adiante. Aliás, ele atribui o barulho na casa de Antônio Pereira aos pretos, 
identificados por ele como músicos da Floresta Aurora, que seriam em número de nove, "mas que se ignora os nomes".

Finalmente, é chamado a testemunhar o carpinteiro Jacinto Bonifácio, de 20 anos de idade, solteiro, morador na rua dos Andradas, nascido em Porto Alegre, alfabetizado. Ele confirma tudo que já havia sido dito anteriormente, diz que na venda do réu havia apenas mais um homem, um carroceiro, que ele não conhecia. Assim como seus companheiros Paulo e Teodoro, Jacinto em seu depoimento cita Felicíssimo Manoel de Azevedo, vizinho da venda, que teria comentado que "o acusado costumava mesmo dar bordoadas em todos, pelo que muitos vizinhos o temiam". Felicíssimo era indivíduo muito conhecido na capital da província, o que podemos atestar por ter sido citado apenas com o prenome no primeiro depoimento, já que todos sabiam a quem Paulo Batista se referia. Ele nasceu em Porto Alegre em 1823 e faleceu na mesma cidade em 1905, estudando com o cronista e professor Antônio Álvares Pereira Coruja. Felicíssimo atuou como empregado no comércio e dentista e "liderou o primeiro Clube Republicano de Porto Alegre, sendo eleito vereador em 1887. Após a República, presidiu a primeira junta administrativa da capital, de janeiro de 1890 a novembro de 1891. Com o pseudônimo de Fiscal Honorário, publicava crônicas sobre assuntos municipais". ${ }^{10}$

Jacinto Bonifácio disse que conhecia o queixoso apenas de vista, mas sabia que ele era trabalhador e morigerado; já o réu, tem ouvido falar mal dele e que agredira o carpinteiro Medina, o oficial de justiça Marciano e o tipógrafo Barbosa. Saliente-se que Jacinto diferenciou os três indivíduos agredidos pelo taberneiro português pela profissão, o que nos mostra a importância que aquele grupo de indivíduos negros dava à inserção profissional, ou seja, o trabalho (principalmente o especializado, daí o destaque ao ofendido ser oficial carpinteiro) era uma insígnia de prestígio social, vinculado à honra e à masculinidade, já que a experiência laboral garantia o sustento individual e familiar.

Como já dissemos, a forma como os músicos da Floresta Aurora (já que nos parece que esse caso de 1880 configura uma agência mais coletiva do que individual) conduzem a queixa contra o vendeiro português evidencia conhecimento dos protocolos exigidos de uma ação judiciária e policial. Em 14 de abril daquele mesmo ano de 1880, o queixoso Eduardo consegue provar com documentos públicos duas agressões cometidas anteriormente pelo réu Antônio Marcos Alves Pereira, o que o ajudavam a representá-lo como sujeito belicoso. Em 25 de junho de 1878, o oficial de justiça Marciano Xavier Gomes requereu ao juiz de Direito da $1^{\text {a }}$ Vara,

10 FRANCO, Sérgio da Costa. Dicionário político do RGS. 1821-1937. Porto Alegre, Suliane Arte e Vida, 2010, p. 32. ROSA, op. cit., p. 106. 


\section{PAULO ROBERTO STAUDT MOREIRA}

reclamando de ter sido "atrozmente injuriado e espancado às 7 horas da noite, mais ou menos da noite" pelo réu. A pedido do solicitador Cornelio Bonone, Marciano foi à taberna do réu, na rua do Riachinho, perto da ponte de pau do Menino Deus, para avisar um indivíduo chamado Manoel Paulo, "que ali parava", que fosse receber os $300 \$$ réis que ele cobrara de Basílio Ferreira da Silva. Lá chegando, estava dando o recado a Manoel Paulo quando o taberneiro lusitano passou a injuriá-lo de ladrão, filho da puta, safado e canalha, em altas vozes, por ter citado seu amigo Basílio. O oficial de justiça recuou para a porta, sendo atacado de surpresa por Antônio Marcos armado com um canivete ou punhal.

Outro documento conseguido pelo queixoso, o carpinteiro e músico Eduardo, foi uma denúncia dirigida ao delegado de polícia, em 14 de abril de 1880, por João Paulino da Silva Barbosa. João Paulino conta que no dia 10 daquele mesmo mês e ano, às 11 horas do dia, foi à taberna de Marcos para tomar cerveja, mas como a que foi servida estava arruinada, ele não quis pagar e ao retirar-se do estabelecimento foi agredido pelo réu com um tinteiro de chumbo na cabeça.

Os detalhes do que temos exposto até aqui evidenciam que, ao adentrarem na esfera policial e judiciária, esses indivíduos negros recebiam um tratamento diferenciado e francamente avesso à legitimidade de suas demandas. Isso não diminui a importância de suas ações reivindicatórias, já que tensionando, mesmo que quixotescamente, as estruturas legais vigentes, eles testavam os limites dos significados de liberdade, autonomia e cidadania, provocando debates que certamente se espraiavam pelas ruas, jornais e associações, suscitando e consolidando conscientizações das formas como a raça (a cor) influenciava e condicionava as hierarquias sociais.

O réu, nos depoimentos dados e nos ofícios dirigidos para as autoridades, defende que ele é que foi agredido e que a sua casa de negócio foi estragada pelos músicos da Floresta Aurora. Quanto à denúncia, tem o fim apenas de tirar-Ihe algum dinheiro, e que quanto aos depoimentos: "Cada testemunha é um réu falando em seu próprio interesse". A sua narrativa do que aconteceu no domingo da Ressurreição de 28 de março de 1880 é de que entraram em sua venda uns homens de cor pedindo cachaça, o que foi recusado pelos caixeiros, por estarem já muito espiritualizados. Os homens de cor então saíram e passaram a arremessar pedras quebrando vidraças e um lampião. Um auto de corpo de delito feito na taberna, na estrada da Azenha, confirmou haver algumas vidraças quebradas e uma marca na porta causada por "corpo duro como pedra, pau ou outro semelhante".

Interessante nesta narrativa elaborada pelo taberneiro português é que ele racializa os músicos da Floresta Aurora, chamando-os de homens de cor. Não os 
chama de negros, pois não eram escravizados ou desclassificados, eram homens conhecidos na cidade e todos tinham profissões especializadas, mas ele não deixa de demarcar a negritude do grupo, procurando estabelecer subalternidade. Ao longo do processo também parece haver um embate na questão da ingestão de bebidas e do tipo de bebida ingerida. O vendeiro insiste na ideia de que os agressores negros ou de cor tinham bebido cachaça, enquanto eles afirmavam que só consumiram (e moderadamente) cerveja, a qual insistem terem pago ou que o dinheiro havia sido deixado em cima do balcão. Norbert Elias mostrou como a etiqueta torna mais visíveis as hierarquias sociais; desse modo, o tipo de bebida que se consome, o comportamento público que se adota ao beber, podem indicar ou influenciar a depreciação ou o apreço comunitário dos atores sociais e com isso (des)legitimar demandas levadas aos órgãos públicos, como a polícia ou a justiça. ${ }^{11} \mathrm{~A}$ associação entre a falta de decoro comportamental e a cor dos envolvidos, parece-nos um discurso racializado, indicando uma política cotidiana de relacionar comportamentos desregrados e pertencimento étnico-racial.

Em 22 de setembro de 1880, o juiz de Direito julgou procedente a ação e é estabelecida uma fiança de 1:600\$ réis, para a qual o réu apresenta dois comerciantes como fiadores. O autor carpinteiro seguia o caso com atenção e no dia 4 do mês seguinte pede a prisão do réu, já que o seu requerimento de fiança não tinha se realizado. $O$ réu finalmente presta fiança provisória em 7 de julho de 1880, a qual se encerra no final de novembro, quando o autor pede novamente a prisão do réu, parecendo que encarcerá-lo seria uma meta do grupo ofendido, já que isso causaria depreciação social do taberneiro agressor e desafrontaria os músicos da Floresta Aurora. Repentinamente, em 24 de novembro de 1880, talvez tendo feito um acerto com o réu, o que não aparece em detalhes no processo, o carpinteiro Eduardo José Ferreira desiste da ação. ${ }^{12}$

\section{"Somos negros na cor, e não especuladores": a Floresta Aurora}

Em sua dissertação defendida em 1999, intitulada As contas do meu rosário são balas de artilharia - Irmandade, jornal e sociedades negras em Porto Alegre 1889-1920, a historiadora Liane Susan Muller destacava a importância para o associativismo negro meridional da atuação dos irmãos ligados à Irmandade de

11 ELIAS, Norbert. O processo civilizatório. V. 2. Formação do estado e civilização. Rio de Janeiro: Zahar, 1993. p. 17.

12 APERS - Juízo de Direito do $2^{\circ}$ Distrito Criminal de Porto Alegre, Sumário, auto 1401, maço 53. Autor: Eduardo José Ferreira. Réu: Antônio Marcos Alves Pereira. 
Nossa Senhora do Rosário de Porto Alegre, criada em 1786. Segundo Muller, ${ }^{13} \mathrm{O}$ pleno funcionamento e as variadas atividades dos irmãos do Rosário de Porto Alegre auxiliaram na construção de um "grupo diferenciado de negros, uma espécie de 'elite' intelectual e proprietária que, a partir de 1870, buscou ampliar seu espaço social fundando clubes, associações beneficentes e até mesmo um jornal". Dessas experiências associativas teria surgido, por exemplo, a Sociedade Floresta Aurora, mesmo que isso não exclua ou diminua o fato dos músicos dessa associação terem o Senhor do Bom Fim como seu padroeiro e também frequentarem outras irmandades como, por exemplo, a da Nossa Senhora da Conceição, conhecida como a dos pardos de Porto Alegre. ${ }^{14}$

A Sociedade Floresta Aurora foi formada, conforme Liane Muller, por um grupo de indivíduos que pertenciam à Irmandade do Rosário e constituíram formas organizativas de caráter civil que eram autônomas à própria Irmandade. Essa associação foi o primeiro clube social formado por afrodescendentes em Porto Alegre. Surgida em 1872 como Sociedade Musical, com o passar dos anos a Sociedade Floresta Aurora desdobrou-se em diversas ramificações que atendiam suas distintas finalidades. Tornou-se sociedade dançante e beneficente, agregou um centro dramático e um centro de "moças", apresentava ainda outra divisão denominada Recreio Floresta Aurora, destinada a atividades de lazer, e também constituiu outra banda de música, denominada Sociedade Musical Lyra Florestina, fundada em 1898. [...] interessa pontuar que: a Sociedade Floresta Aurora surgiu como entidade musical; a Irmandade do Rosário era influente quando de sua fundação, visto que seus fundadores eram irmãos dessa mesma instituição religiosa; embora apresente diversas ramificações, o seu núcleo central era denominado de Sociedade Floresta Aurora e apresentava mais de uma banda de música, sendo a principal referenciada como Banda da Floresta Aurora (a outra era a Lyra Florestina). ${ }^{15}$

Nara de Jesus ${ }^{16}$ afirma que a Floresta Aurora teve desde o seu surgimento um caráter beneficente "para auxiliar famílias negras em caso de óbito, custeando o funeral e prestando assistência, segundo histórico da própria entidade", o que

13 MULLER, Liane Susan. As contas do meu rosário são balas de artilharia. In: SILVA, Gilberto Ferreira da; SANTOS, José Antônio do Santos. RS: negro - cartografias sobre a produção do conhecimento. Porto Alegre: EDIPUCRS, 2009. p. 267-268.

14 TAVARES, Mauro Dillmann. Irmandades religiosas, devoção e ultramontanismo em Porto Alegre no bispado de Dom Sebastião Dias Laranjeira (1861-1888). 2007. Dissertação (Mestrado em História) - Universidade do Vale do Rio dos Sinos, São Leopoldo, 2007. ALMEIDA, Vinicius Furquim de; MOREIRA, Paulo. Os pardos da Imaculada: trajetórias e agências negras na Irmandade de Nossa Senhora da Conceição de Porto Alegre (século XIX). Métis (UCS). v. 16, p.141-172, 2017.

15 BOHRER, Felipe Rodrigues. A música na cadência da história: raça, classe e cultura em Porto Alegre no pós-abolição. 2014. Dissertação (Mestrado em História) - Universidade Federal do Rio Grande do Sul/ PPGH, Porto Alegre, 2014. p. 95-96.

16 JESUS, Nara Regina Dubois de. Clubes sociais negros em Porto Alegre - RS: a análise do processo de recrutamento para a direção das associações Satélite, Prontidão e Floresta Aurora, trajetórias e a questão da identidade racial. 2005. Dissertação (Mestrado em Sociologia) - Instituto de Filosofia e Ciências Humanas, Universidade Federal do Rio Grande do Sul, Porto Alegre, 2005. p. 10 e 45. 
aproxima as funções desse associativismo com o das irmandades. Jesus ainda amplia esse caráter beneficente, informando que "as associações ou clubes sociais negros, em Porto Alegre, emergem como uma certa tomada de consciência de uma parcela da população negra que tinha como objetivo resolver problemas relativos a interesses materiais e, principalmente, aspirações de ascensão social". Criada no pré-1888, a memória dos atuais mantenedores do clube vivifica esse protagonismo com a legenda "Mais antiga que a própria liberdade de seu povo".

No último dia do ano de 1872, 31 de dezembro, foi fundada a Sociedade Beneficente Floresta Aurora, apesar de seu primeiro livro de registro ter a data de 15/12/1872. Existem algumas versões a respeito da poética denominação dessa sociedade. A versão mais conhecida afirma que alguns jovens músicos negros retornavam de uma serenata pela rua da Floresta (atual avenida Cristóvão Colombo), discutindo sobre a pertinência da fundação de uma agremiação que os representasse e o nome surgiu do cruzamento do nome da via pela qual transitavam com o nascimento do dia, a alvorada ou aurora, o que demarcaria o horário em que aqueles boêmios circulavam. Outros, reticentes ao encanto dessa primeira versão, ou complementando-a, alertam que o título da sociedade não seria uma referência somente ao horário em que os músicos decidiram pelo nome dessa longeva associação, mas pelo fato de estarem cruzando a rua da Aurora, que até 1857 era conhecida como beco do Barbosa, e que em 1916 foi renomeada em homenagem ao republicano João Barros Cassal, primeiro chefe de polícia pós-1889 e diretor do jornal A Federação. ${ }^{17}$

Como viver sobre si era importante, a Floresta Aurora tratou de obter endereços próprios. Sua primeira sede foi na rua do Riachuelo (antiga da Ponte), próximo à Caldas Júnior, no centro de Porto Alegre; em 1885, a sociedade mudou-se para outra sede muito próxima, na travessa Paissandu (antigo beco do Fanha e hoje Caldas Júnior). Depois, com o aumento do número de sócios e de atividades, a sociedade saiu do centro de Porto Alegre indo para o atual bairro Cidade Baixa, onde adquiriu sede própria na rua Concórdia n 55 (atual José do Patrocínio), e "ao mesmo tempo, adquire um grande terreno na rua da Olaria, hoje Lima e Silva, quase esquina com a rua Sarmento Leite, para ali construir uma sede mais ampla. $\mathrm{O}$ terreno custou a alta soma de um conto e duzentos e cinquenta mil réis. Corria então o ano de 1908. Quatro anos depois, a nova sede foi inaugurada festivamente". ${ }^{18} \mathrm{~A}$

17 FRANCO, Sérgio da Costa. Dicionário político do RGS. 1821-1937. Porto Alegre, Suliane Arte e Vida, 2010. Idem. Porto Alegre. Guia Histórico. Porto Alegre: Editora da UFGRS, 1988.

18 Segundo Nonnenmacher, até a construção dessa sede própria, a sociedade fazia seus bailes no teatro São Pedro e, entre outros lugares, na casa onde morava Aurélio Viríssimo de Bittencourt, na General João Manoel, entre a Riachuelo e Andradas. NONNENMACHER, Marisa Schneider. Tudo começou em uma madrugada. Sociedade Beneficente Cultural Floresta Aurora (1872-2015). 
Floresta Aurora afirmava, assim, sua presença em um espaço da cidade onde era elevada a presença de trabalhadores "de cor", sendo conhecida como "a sociedade de pretos da Lima e Silva". Talvez a aquisição de sede própria nesse arrabalde de Porto Alegre, marcado pela presença negra, tenha se dado pelo preço dos imóveis, mais em conta do que no centro administrativo e comercial da capital da província. Depois, a Floresta Aurora mudou-se para a rua Curupaiti (bairro Cristal), e hoje em dia está na avenida Coronel Marcos, no bairro Pedra Redonda. ${ }^{19}$

Em 27 de dezembro de 1878, na sua página 2, o Jornal do Comércio, editado em Porto Alegre, publicou a nominata da diretoria da Floresta Aurora que atuaria no ano de 1879. Eram eles:

Presidente: Isidoro Francisco Xavier;

Vice-Presidente: Paulo Baptista da Silva;

$1^{\circ}$ Secretário: Agostinho Ferreira dos Santos;

$2^{\circ}$ Secretário: Polidoro Antônio de Oliveira;

Tesoureiro: Miguel Arcanjo da Cunha;

Diretores: Anacleto Antônio de Freitas, Modesto Carlos dos Santos, João Antônio Ferreira, Israel Antônio dos Santos, José Paulo Dias, Climério Fortunato da Silva;

Comissão de Contas: Casemiro Luciano de Freitas, Bernardino Manoel dos Santos, Adão de Meneses.

O Jornal do Comércio, desde 1874, era propriedade da firma Silva, Candal e Cia., sendo um dos acionistas ou co-proprietário o funcionário público negro (ou pardo, segundo os documentos da época) Aurélio Viríssimo de Bittencourt. Aurélio conseguiu o capital necessário de um empréstimo de 3 contos e 400 mil réis, feito com o $1 / m$. ${ }^{\circ}$ Senhor $1^{\circ}$ tenente da Armada Hipólito Simas de Bittencourt, conforme nota promissória passada em 21 de agosto de 1875, em Porto Alegre, "para ocorrer ao pagamento da $1^{a}$ prestação da tipografia do Jornal do Comércio e da parte que me coube na encomenda de uma máquina de impressão para a mesma tipografia". ${ }^{20}$ Aurélio nasceu em Jaguarão, cidade na fronteira com o Uruguai, e era filho natural da parda Maria Júlia da Silva, amasiada com o então piloto extranumerário da Armada Hipólito Simas de Bittencourt. Essa

Porto Alegre: Medianiz, 2015. p. 53.

19 Ibidem, p. 41 e 53. GERMANO, Iris Graciela. Rio Grande do Sul, Brasil e Etiópia: os negros e o carnaval de Porto Alegre nas décadas de 1930 e 40. 1999. Dissertação (Mestrado em História) - Universidade Federal do Rio Grande do Sul/PPGH, Porto Alegre, 1999. p. 242. JESUS, op. cit., p. 10 e 52. Ver também: LAZZARI, Alexandre. Certas coisas não são para que o povo as faça: carnaval em Porto Alegre 1870-1915. 1998. Dissertação (Mestrado em História) - Universidade Estadual de Campinas - Unicamp, Campinas, 1998.

20 APERS - Cartório da Provedoria de Porto Alegre, 1884, inventário 622, maço 36. Inventariado: Hipólito de Simas Bittencourt. Inventariante: Leocádia Virginia de Castro. 
ilegitimidade do nascimento de Aurélio (o qual consta em seu batismo como filho de pais não conhecidos) não significou o afastamento ou abandono dele com seu pai, que aparentemente sempre o apoiou como podia. Mesmo assim, quando de seu casamento em 1868, na igreja do Rosário de Porto Alegre, Aurélio aparece com o sobrenome Conceição, pois parece que só em seu testamento de novembro de 1883 é que Hipólito assumiu publicamente a paternidade de seu filho pardo. Portanto, o empréstimo de 1874 era na verdade um adiantamento da herança de Aurélio, já que foi dele cobrado apenas no inventário post mortem de seu pai, em 1884.

Fizemos essa digressão pelo coproprietário do Jornal do Comércio, Aurélio Viríssimo de Bittencourt, porque ele aparecerá novamente adiante em nossa narrativa. Além disso, consideramos importante demarcar a presença desse funcionário público negro nesse órgão de imprensa, pois ele não pode ser desvinculado, nesse contexto histórico, de sua afiliação ao Partido Liberal. Aliás, segundo a pesquisadora Marisa Nonnenmacher, as novas diretorias da Floresta Aurora eram corriqueiramente noticiadas no Jornal do Comércio, o que nos parece evidenciar a relação desse coletivo negro com o Partido Liberal, principalmente durante a vigência do Império.

Quanto às ligações do coproprietário do Jornal do Comércio com a Floresta Aurora, nas comemorações do 13 de maio de 1904, o jornal negro O Exemplo estampou na sua primeira página uma foto do tenente-coronel da Guarda Nacional Aurélio Viríssimo de Bittencourt, personalidade da comunidade negra local,

[...] e dedicando-Ihe longo editorial, no qual salientaram suas contribuições como sócio benemérito da sociedade Floresta Aurora e Sociedade Beneficência Porto Alegre, prior na Confraria Nossa Senhora do Rosário e líder do movimento abolicionista gaúcho, quando atuou como porta-voz dos primeiros manifestantes que saudaram a abolição, no 13 de maio de 1888, em Porto Alegre. Aurélio de Bittencourt foi representado como "o maior atleta na luta pela conquista dos direitos civis e políticos dos negros". Desta forma, O Exemplo construía modelos de conduta que serviriam de referência para a comunidade negra. ${ }^{21}$ [grifos nossos]

Dois nomes da nominata de 1879 são conhecidos dos leitores deste artigo: o presidente e sacristão da igreja das Dores, Isidoro Francisco Xavier (que voltou à presidência da Floresta Aurora em 1882) e o vice-presidente e carpinteiro Paulo Baptista da Silva (que também foi secretário, membro da comissão de contas, em 1882, $1^{\circ}$ secretário em 1887 e diretor em 1890). Enquanto músicos ligados à Floresta Aurora, Isidoro e Paulo acompanharam um enterro ao cemitério, naquele domingo da Ressurreição de 1880, e depois se envolveram em um conflito com um taberneiro português.

21 ZUBARAN, Maria Angélica. Comemorações da liberdade: lugares de memórias negras diaspóricas. Anos 90, v. 15, p. 161-187, 2008, p. 177. 


\section{PAULO ROBERTO STAUDT MOREIRA}

A inserção social e profissional dos indivíduos filiados à Floresta Aurora, que apareceram naquele conflito de 1880, demonstra que eles exerciam profissões manuais especializadas (pedreiros, carpinteiros) muito demandadas em um núcleo urbano crescente como Porto Alegre. Claro que, em uma cidade em crescimento, certas profissões (advindas de uma formação iniciada na escravidão ou não) se tornam muito requisitadas, fazendo crescer em prestígio os seus integrantes. Carpinteiros, pedreiros etc. eram muito requisitados nas diárias obras públicas, consertos de residências e também na construção das novas edificações que abrigariam os moradores que chegavam através da (i)migração.

É possível que aqueles indivíduos negros que desciam do cemitério da Santa Casa, naquela manhã de 28 de março de 1880, constituíssem a banda da Floresta Aurora, criada poucos anos antes, em 1877. Entretanto, apesar de serem descritos pela autoridade policial como músicos (além de pretos), eles mesmos não se apresentavam como tais, parecendo assim que essa atividade era paralela aos exercícios de seus ofícios efetivos e que também - pelo menos nas esferas policiais e judiciárias - ser músico poderia trazer algum desprestígio social mais do que prestígio. Além disso, esses músicos populares provavelmente não exerciam essa arte profissionalmente, o que não os desqualificava em termos de suas habilidades artísticas, mas apenas mostra como o circuito musical de Porto Alegre era ainda majoritariamente amador. De qualquer forma, a música era um mecanismo de projeção social bastante eficiente, já que a banda da Floresta Aurora aparecia em circunstâncias lúdicas, religiosas ou políticas, abarcando um leque amplo de acontecimentos sociais. Em 12 de janeiro de 1881, o Jornal do Comércio publicou que:

Hoje, às 7 horas da manhã, reúnem-se nas salas das sessões os sócios da sociedade de dança beneficente Floresta Aurora para, incorporados, irem assistir, na igreja de N. S. da Conceição, à missa do Senhor do Bonfim, padroeiro da associação. De volta do ato religioso, será empossada a diretoria que tem de servir no ano presente. A banda de música desta sociedade tocará hoje, na ermida do Senhor do Bonfim, escolhidas peças de seu repertório, das 7 às 8 horas da manhã. [grifos nossos]

Em $1^{\circ}$ de novembro de 1880 faleceu o então senador José Maria da Silva Paranhos, o Visconde do Rio Branco, famoso pela apresentação e promulgação da Lei do Ventre Livre, de 28 de setembro de 1871. Autodenominando-se como modestos filhos do povo, os integrantes da Floresta Aurora trataram de prestar homenagens a esse político, conforme noticiou o órgão de imprensa do Partido Liberal, A Reforma, em 16 de novembro de 1880: 
Tiveram lugar ontem as solenes exéquias promovidas pela Sociedade Floresta Aurora como uma homenagem à memória do venerando cidadão, que se chamou José Maria da Silva Paranhos, e que deixou o seu nome ligado a tantos e tão importantes benefícios de que goza hoje o país.

A simples, mas sincera, manifestação dos modestos filhos do povo mostra o grau de estima e apreço em que era tido o ilustre finado e diz tanto como as ruidosas solenidades que se tem feito e que se possam fazer depois de sua morte, para honra de seu nome e de sua memória.

Ao ato compareceu o senhor presidente da província, acompanhado de seu secretário e oficial de gabinete, o general comandante das armas, o senhor presidente da Câmara Municipal, conselheiro Queiroz Barros; desembargador Brusque; juízes de direito drs. Orlando e Flores; cônsul português; chefes e empregados de repartições gerais e provinciais e muitos outros cavalheiros.

Terminadas as cerimônias religiosas, recitaram discursos o tenente José Joaquim de Vasconcellos, como representante da Sociedade Emancipadora Rio Branco, o sr. Alfredo Duarte, da Sociedade Literária José de Alencar, e o sr. Aurélio Viríssimo de Bittencourt, da Tipográfica.

Na peça, que estava decentemente adornada, estava o retrato do Visconde do Rio Branco circundado de grinaldas.

A Sociedade Floresta Aurora compareceu, com fumo no braço e com seu estandarte coberto de crepe, executando uma marcha fúnebre, antes e depois das exéquias.

Esteve no coro o músico e maestro Mendanha.

A justiça da posteridade começa já a sua obra e há de colocar o Visconde do Rio Branco no número de beneméritos da pátria, como os seus contemporâneos já o tinham sagrado um dos primeiros homens do Império. [grifos nossos]

Em $1^{\circ}$ de janeiro de 1885, a Banda Musical Floresta Aurora recepcionou o casal imperial, formado pelo Conde d'Eu e pela Princesa Isabel, quando este passou por Porto Alegre em sua viagem pela província meridional, durante os meses de janeiro a março de 1885, sendo assaz ironizada pelos republicanos gaúchos. Aliás, já em 31 de outubro do ano anterior, os republicanos já atacavam os arranjos para a chegada do casal imperial no artigo "O peditório para a chegada dos príncipes", em que ironizavam as arrecadações de fundos para que os "amigos de suas altezas imperiais tenham o inefável prazer de recebê-los sob arcos de verdura e ao som dos hinos da Floresta Aurora e de outras filarmônicas". ${ }^{22}$ Mas, em janeiro de 1885, na véspera da chegada dos príncipes, a ironia dos republicanos tornou-se ainda mais agressiva, sendo simulados telegramas que seriam publicados nos dias posteriores, com frequentes menções à Floresta Aurora e sua simpatia com a família imperial. Segundo A Federação, os jornais locais publicariam "edições especiais em honra das altezas, menos A Federação":

22 A Federação, ano I, n. 252 - HDBN. 
À noite, um grandioso baile de gala. A cidade toda iluminada, o povo percorrendo as ruas ao som de hinos, discursos, foguetes, poesia, Floresta Aurora. No dia seguinte, altezas imperiais aparecendo na sacada, o povo postado na calçada para esperar em aclamações ao som de hinos, discursos, foguetes, Floresta Aurora. ${ }^{23}$

Mas o sarcasmo republicano não ficou sem resposta e veio justamente através do Jornal do Comércio, que participou ativamente das comemorações relativas à recepção do casal imperial.

A Federação quis expor ao ridículo a Sociedade Musical Floresta Aurora nos seus debiques à chegada dos príncipes. Perdera o seu tempo; exposto ao ridículo ficam os desfrutáveis que não se respeitam, e não uma sociedade de artistas que se prezam e sabem se conduzir pelo bom caminho. Se é o fato de sermos de cor, o que motivou as suas graçolas, isto dá ideia da pureza dos princípios que advoga.

Somos negros na cor, e não especuladores.

(Assinado) Um crioulo. ${ }^{24}$

Novamente reforçamos o fato de que os músicos da Floresta Aurora, assim como o coproprietário do Jornal do Comércio (Aurélio Viríssimo de Bittencourt), aparecem muito próximos dos liberais, usando um dos órgãos de imprensa ligados ao Partido Liberal como porta-voz de suas expectativas e protestos. O pequeno trecho acima joga sobre os republicanos o epíteto do preconceito racial, usando designações autorreferenciais como de cor, negros na cor e crioulo. A palavra crioulo aqui é usada como artifício discursivo de provocação, servindo para explicitar o racismo do órgão republicano. Trata-se de uma palavra que, no vocabulário racial da época, tem um grave sentido pejorativo e aqui os militantes do associativismo negro a usam invertendo o seu papel de estigma racial, manejando-a em uma ostensiva ofensiva ao preconceito de cor. Esse curto A Pedido configura-se como uma antecipação do que a imprensa e os intelectuais negros ${ }^{25}$ tratarão posteriormente de forma insistente, provocando a "herança da escravidão" e questionando as delimitações das noções de liberdade e cidadania. ${ }^{26}$ Assumir-se crioulo era denunciar o racismo alheio e com

23 A Federação, $1^{\circ}$ jan. 1885, ano II, n. 1 - HDBN.

24 Jornal do Comércio, p. 4, 4 jan. 1885.

25 SANTOS, José Antônio dos. Prisioneiros da história. Trajetórias intelectuais na imprensa negra meridional. 2011. Tese (Doutorado em História) - Pontifícia Universidade Católica do Rio Grande do Sul, Porto Alegre, 2011.

26 Silvia Lara tem mostrado como bem antes da abolição definitiva da escravidão circulavam e se digladiavam "noções diferentes de liberdade e de trabalho livre". Marília Ariza, após fazer uma revisão da historiografia brasileira que já se debruçou sobre os significados da liberdade, conclui que: "Tornar-se livre significava, em muitas medidas, cultivar uma autonomia que não se enunciava como estatuto jurídico, mas que se materializava no dia a dia dos trabalhadores, de modo que a liberdade tornava-se um ofício cotidiano" (ARIZA, Marilia Bueno de Araújo. O ofício da liberdade. Trabalhadores libertandos em São Paulo e Campinas (1830-1888). São Paulo: Alameda, 2014. p. 45. LARA, Silvia. Escravidão, cidadania e História do Trabalho no Brasil. Projeto História. v. 16, p. 25-38, fev. 1998). 
isso acirrar o debate sobre os significados políticos envolvidos nas classificações por cor, parecendo-nos que aí estava presente também a cidadania, principalmente através do eleitorado negro, ponto que pode ser visualizado no título do presente artigo e que será retomado adiante.

\section{Cumpre afugentar os negros para sossego da vizinhança}

A imprensa oitocentista era majoritariamente político-partidária. Aliás, era ostensivamente partidária, sendo os seus pronunciamentos logo percebidos pelos leitores como posicionamentos dos partidos em questão. Em 1874, João Câncio Gomes fundou o jornal Mercantil, o segundo periódico com este nome a circular por Porto Alegre. ${ }^{27}$ Câncio Gomes não tinha ligação efetiva com nenhum dos partidos políticos existentes, mas seu posicionamento sempre oscilava a favor dos conservadores. ${ }^{28}$ Com relação ao atrito entre os pretos da Floresta Aurora e o taberneiro português, o jornal Mercantil traça uma narrativa do acontecimento que se afasta da adesão a algum dos lados em conflito, mas que alerta para os riscos de que a privatização do conflito (sem a devida ação pública) pudesse gerar uma desarmonia social grave, tendo em vista o componente racial ali presente.

PORMENORES - em adiantamento à notícia que ontem demos
sobre o vendeiro que feriu a cabeça de um preto, comunicam-nos o
seguinte: "Os companheiros do preto ofendido, atendendo a seu
estado lastimoso, e a justiça da terra marchar a passo de boi,
resolveram tomar o desforço por suas mãos, e preparados de
azorragues rondam as cercanias da venda no firme propósito
de aplicarem uma esfregação no tal inimigo das cabeças. À
última hora, corria por uns que os pretos já haviam aplicado o
corretivo; para outros, que ainda não. Em todo caso, chamamos a
atenção do Sr. Dr. Chefe de Polícia para essas cenas da Várzea,
tão reproduzidas. A vizinhança vive indignada com o vendeiro e
sobressaltada com a ronda negra; cumpre afugentar os negros
para sossego da vizinhança e aplacar a febre do vendeiro em
partir cabeças, para a tranquilidade dos transeuntes. Informam-
-nos que o ativo subdelegado, o sr. Madeira, está procedendo o
inquérito sobre o ferimento (Mercantil, $1^{\circ}$ de abril de 1880 - MCHC).
[grifos nossos]

27 Câncio Gomes (1836-1889), aos 15 anos de idade, começou a trabalhar na imprensa local como tipógrafo, em um jornal homônimo ao seu (de propriedade de Félix Xavier da Cunha); em 1861 era empregado na tipografia do periódico A Ordem, depois foi chefe da oficina do jornal Rio-Grandense; em 1872 fundou o órgão literário Álbum Semanal. Fez parte da comissão conservadora para a libertação imediata de escravos e dos indivíduos contratados do $3^{\circ}$ Distrito da capital, conforme deliberado no meeting abolicionista de 8 de dezembro de 1887 (Mercantil, Porto Alegre, 9 dez. 1887. MCHC).

28 BAKOS, Margaret Marchiori. RS: escravismo e abolição. Porto Alegre: Mercado Aberto, 1982. MOREIRA, Paulo. Os cativos e os homens de bem. Experiências negras no espaço urbano. Porto Alegre: Edições EST, 2003. 


\section{PAULO ROBERTO STAUDT MOREIRA}

De certa forma vitrine da ação estatal, as tabernas deveriam ser pontos privilegiados de vigilância. A lentidão dos mecanismos policiais e judiciários (que marchavam "a passo de boi") não podia ocasionar a privatização da resolução dos conflitos, o que podia resultar na mobilização da cidade solidária (na forma de "ronda negra"), com as classes populares (e principalmente sua facção perigosa) tomando a justiça em suas mãos. O jornal racializa o acontecimento, descrevendo-o como um enfrentamento entre pretos e o vendeiro inimigo das cabeças (aí não mencionado em sua lusitanidade), reivindicando a ação rápida dos órgãos públicos de controle social, com a intenção primordial de amenizar o conflito, impedindo que a tensão racial se espraiasse com a agência autônoma daquele coletivo negro (ou preto). Destaquemos que talvez aquele coletivo de músicos tivesse cogitado, em algum momento, tomar a justiça em suas próprias mãos, elemento que não aparece no documento judiciário que estamos manejando. Talvez o próprio Isidoro Francisco Xavier tenha insistido que deveriam recorrer, procurando reparação material e simbólica (moral) aos órgãos públicos, diluindo assim aquela ronda negra, que podia nem ser formada pelos músicos agredidos, mas por outros membros das comunidades negras locais, injuriados em solidariedade aos seus parceiros de cor.

Isidoro Francisco Xavier casou-se em 25 de janeiro de 1873, às 7 e meia da noite, na igreja das Dores, em Porto Alegre, com Estela Luiza Valentina, ambos naturais desta província e filhos naturais, ele de Mariana Luiza do Livramento, e ela de Felicidade Maria da Conceição. ${ }^{29} \mathrm{Na}$ habilitação de casamento, os noivos pediram dispensa da apresentação dos registros de casamento por quererem "efetuar com a máxima brevidade o seu consórcio". Testemunharam o consórcio o doutor Amadeu Prudêncio Masson e Lino Carvalho da Cunha e Silva.

Isidoro, como já mencionamos, possuía bom trânsito social, situação certamente influenciada pela sua atividade de sacristão da igreja de Nossa Senhora das Dores, localizada na rua dos Andradas, centro comercial da capital da província. Nos registros de batismos de ingênuos daquela paróquia, o encontramos frequentemente estabelecendo apadrinhamentos:

29 AHCMPA $-1^{\circ}$ Livro de Casamentos da Paróquia de Nossa Senhora das Dores, folha 90/AHCMPA - Habilitações de casamento, ano 1873, n. 125, caixa 279. 
Batismos de ingênuos, igreja das Dores - padrinho: o sacristão Isidoro Francisco Xavier

\begin{tabular}{c|c|c|c|c|c}
\hline Batismo & Nome & Mãe & Nascimento & Senhor & Madrinha \\
\hline $19 / 7 / 1872$ & Sabino & Sofia & $11 / 7 / 1872$ & $\begin{array}{c}\text { Antônio Álvaro } \\
\text { de Araújo }\end{array}$ & Nossa Sra. \\
\hline $27 / 2 / 1874$ & Felizarda & Carlota & $29 / 11 / / 1874$ & $\begin{array}{c}\text { Francisco José Pires } \\
\text { (herança de) }\end{array}$ & $\begin{array}{c}\text { N. Sra da } \\
\text { Conceição }\end{array}$ \\
\hline $17 / 6 / 1875$ & Feliciana & Cândida & $12 / 4 / 1875$ & $\begin{array}{c}\text { Antônia Benedita } \\
\text { de Oliveira Knorr }\end{array}$ & $\begin{array}{c}\text { N. Sra das } \\
\text { Dores. }\end{array}$ \\
\hline $13 / 2 / 1875$ & Abraão & Francisca & $30 / 11 / 1874$ & João Daniel Collin & $\begin{array}{c}\text { N. Sra. dos } \\
\text { Navegantes }\end{array}$ \\
\hline $15 / 10 / 1874$ & Marcolina & Maria & $3 / 6 / 1874$ & Manoel Machado Toledo & $\begin{array}{c}\text { Maria Rosa da } \\
\text { Conceição }\end{array}$ \\
\hline $11 / 1 / 1879$ & Maria & Maria & $10 / 7 / 1878$ & $\begin{array}{c}\text { Joaquim Pedro Salgado } \\
\text { (Major) }\end{array}$ & $\begin{array}{c}\text { Estela Luiza de } \\
\text { Mendonça }\end{array}$ \\
\hline
\end{tabular}

Fonte: AHCMPA - Livro de Batismos de Ingênuos da Paróquia de Nossa Senhora das Dores,

n. 4, folha 3; livro 3, folhas $82,126,134 v$; livro 3, folha $142 v$; livro 5 , folha 6 ;

Talvez Isidoro Francisco Xavier tenha pedido dispensa de fornecer o seu registro de batismo por não querer que o seu recente passado de escravizado fosse lembrado. Isidoro foi alforriado pela senhora Maria Luíza do Livramento em 2 de outubro de 1855. Ele tinha apenas 8 anos de idade e a sua escravizadora anotou que procedia com tal desprendimento com aquele crioulo "em razão de tê-lo criado e pela muita amizade que Ihe tinha". Mesmo com tanto afeto envolvido, ela condicionou a liberdade do futuro sacristão, que deveria servi-la até o momento em que ela morresse..$^{30}$

No dia anterior ao da alforria acima, em $1^{\circ}$ de outubro de 1855 , foi também alforriada a mãe de Isidoro. Mariana era uma africana, portanto vítima direta da diáspora transatlântica. Foi identificada como mina e ladina, portanto, natural da costa atlântica africana ocidental, mas já acostumada com os hábitos da cultura escravista luso-brasileira. A senhora não foi tão afetiva quanto no documento de liberdade de Isidoro, mas apenas acentuou que "por alguns serviços que me tem prestado durante o seu cativeiro", a alforriava mediante o pagamento, pela escravizada, de um conto de réis, "ficando a mesma restando-me a de $250 \$$, para me dar em pagamento no termo de três meses". Ou seja, a mina Mariana teve que indenizar a sua escravizadora de uma substancial quantia, o que evidencia que a alforria condicional de seu filho estava inserida na negociação pecuniária promovida por sua mãe. Que esforços teve que despender essa africana para libertar a si e seu filho não temos como saber, mas as habilidades relacionais e profissionais que ela carregava foram legadas a seu filho (junto com a alforria) e essas experiências

30 APERS $-1^{\circ}$ Tabelionato de Porto Alegre, Livro 15 de Registros Diversos, 9 jun. 1857, folha 159. 
maternas (os seus protagonismos e afetos) certamente influenciaram e formataram o pertencimento étnico-racial do sacristão Isidoro. ${ }^{31}$

Coincidentemente ou não, a noiva de Isidoro foi alforriada no ano anterior ao de seu marido. Em 6 de julho de 1854 foi redigida uma carta de alforria, em Porto Alegre, que beneficiava a mulata Estela, com apenas 5 anos de idade, filha de Felicidade, ambas escravizadas do maestro Joaquim José de Mendanha. A carta de Estela, assim como a de Isidoro, era condicionada à morte do senhor, o qual justificava sua bondade "atendendo a ter nascido em minha casa e ser a primeira cria". O maestro Mendanha nasceu em Minas Gerais e veio para o Rio Grande do Sul com as tropas legalistas que lutaram contra os farroupilhas. Ele era negro e tornou-se uma figura importantíssima no campo musical sul-rio-grandense. É provável que o maestro Mendanha tenha tido influência na própria criação da Sociedade Floresta Aurora. Destaque-se que, apesar da carta de Estela ser condicional e que a sua alforria, portanto, só valeria com a morte do maestro, que ocorreu em 1885, nada consta sobre o seu status de escravizada na sua habilitação e registro de casamento. É provável que Estela e sua mãe Felicidade tivessem uma boa relação com o seu senhor não branco e que comunitariamente já fosse reconhecida como liberta. ${ }^{32}$

No ano seguinte ao conflito na venda da Azenha, pelas 5 horas da tarde do dia 15 de janeiro de 1881, na matriz de Nossa Senhora do Rosário, "depois de feitas as diligências do estilo, segundo o Sagrado Concílio Tridentino e Constituições do Bispado, e não havendo impedimento", contraíram matrimônio os noivos: o pedreiro Ataliba de Castro Vasconcelos e Maria Amália de Oliveira. Ambos eram naturais daquela província e filhos naturais, ele de Geralda da Cunha, e ela de Rita Joaquina de Oliveira. O padre ministrante foi Hildebrando de Freitas Pedroso e as testemunhas-padrinhos foram Miguel Arcanjo da Cunha e Martinho Nobre de Oliveira (assinou a seu rogo o sacristão, também negro, Frutuoso Vicente Vaz). ${ }^{33}$

Conforme aparece no depoimento de Ataliba de Castro, de 1880, ele era analfabeto. Assim, o requerimento de seu casório junto à Igreja Católica foi feito pelo

31 A senhora Maria Luiza do Livramento não durou muito e por isso a liberdade de Isidoro logo se consolidou. Ela morreu de tísica (tuberculose) no mesmo mês de outubro de 1855, aos 54 anos de idade. Foi descrita como branca, natural de Santa Catarina e filha de Francisco Pedro de Miranda Castro. APERS $-2^{\circ}$ Tabelionato de Porto Alegre, Livro n. 16 de registros diversos, 10 fev. 1857, folha 222. CHC-SCMPA - Livro n. 2 de óbitos de pessoas livres, enterro em 4 out. 1855, sepultura 186 de entremuros, condução carro n. 1 (reg. 3256).

32 APERS $-1^{\circ}$ Tabelionato de Porto Alegre, Livro n. 21 de registros diversos, 22 jan. 1873, folha 225v. MARQUES, Letícia Rosa. O maestro Joaquim José de Mendanha. Música, devoção e mobilidade social na trajetória de um pardo no Brasil oitocentista. 2017. Tese (Doutorado em História) - Pontifícia Universidade Católica do Rio Grande do Sul, PPGH, Porto Alegre, 2017.

33 AHCMPA - Livro $5^{\circ}$ de Casamentos da Paróquia da Nossa Senhora do Rosário, folha 20v/ Habilitação de casamento, ano 1881, n. 42, caixa 301. Noivos: Ataliba de Castro Vasconcelos e Maria Amália de Oliveira. 
amigo Isidoro Francisco Xavier. O padrinho de Ataliba, Miguel Arcanjo da Cunha, foi um dos fundadores da Floresta Aurora. Ataliba e Miguel eram irmãos. Ataliba nasceu em 10 de julho de 1855, em Porto Alegre, sendo batizado em 4 de novembro do mesmo ano, na mesma igreja em que se casou. Ataliba era filho natural da cabra Geralda, escravizada de D. Maria Quitéria de Castro. ${ }^{34}$ A noiva de Ataliba nasceu em Viamão, em 4 de novembro de 1858, sendo batizada na paróquia da Conceição daquele município em 30 de junho do ano seguinte. Era filha da preta Rita Joaquina de Oliveira, ambas escravizadas de Manoel José de Santana.

A senhora dos irmãos Ataliba de Castro e Miguel Arcanjo da Cunha pertencia a uma família de muito prestígio na província. Era viúva do brigadeiro português Francisco Xavier da Cunha, o qual, por volta de 1828, instalou-se em Porto Alegre, onde foi promovido a coronel. Participou ativamente da guerra civil farroupilha (1835-1845) pelo lado legalista, sendo promovido a brigadeiro em 1837 e falecendo em combate dois anos depois. O inventário post mortem do brigadeiro Cunha só foi realizado em 1865, conjuntamente com o de sua viúva Maria Quitéria, sendo inventariante um dos filhos de ambos, Francisco Xavier da Cunha. ${ }^{35}$ Maria Quitéria, falecida em 23 de maio de 1863, havia preventivamente redigido suas últimas vontades em testamento de 4 de julho de 1859. Ela não se casou novamente depois de enviuvar do brigadeiro Cunha, com quem teve quatro filhos: Mariana (já falecida, no estado de solteira), Diogo Xavier da Cunha (solteiro, 38 anos), Dr. Félix Xavier da Cunha e Francisco Xavier da Cunha (casado com Amélia Teixeira da Cunha).

O patrimônio do casal Maria Quitéria e brigadeiro Cunha somava um monte-mor de $24: 874 \$ 752$ réis, sendo 12 contos e 700 mil réis $(51 \%)$ imobilizados numa escravaria composta de 11 indivíduos. Especificamente quanto aos seus escravizados, Maria Quitéria declarou no papel que registrou suas últimas vontades:

Deixo à pardinha Leocádia, filha da crioula forra Camila, sete vacas. Deixo livre por minha morte a minha escrava crioula Giralda [sic]. Quero, outrossim, que o filho da mesma, de nome Ataliba, que nasceu em julho de 1855, seja livre quando completar 28 anos, devendo servir até esta época a meu filho Félix ou a seus herdeiros, mandando aquele ensinar um ofício.

No inventário post mortem de 1865, a crioula Geralda tinha 40 anos e três escravizados são apontados no mesmo documento como seus filhos: Clemência,

34 AHCMPA - Livro $1^{\circ}$ de Batismos de Escravos da Paróquia de Nossa Senhora do Rosário, folha 215v. Foram padrinhos: Geraldino, escravo de Félix José de Mattos, e Maria, crioula, escrava de Dr. João Capistrano de Miranda e Castro.

35 APERS - $2^{\text {a }}$ Vara de Família e Sucessão de Porto Alegre, caixa n. 004.1450, auto 308. Inventariados: Francisco Xavier da Cunha e Maria Quitéria de Castro e Cunha. Inventariante: Francisco Xavier de Cunha, 1865. 
de 5 anos, Ataliba, de 10 anos e Miguel, com 18 anos. Ataliba ainda teria que servir como escravizado àquela família senhorial por mais 18 anos. A outra irmã de Miguel Arcanjo, Clemência, ainda menor, foi alforriada pela família senhorial dos Cunha. Ela foi ainda listada no inventário de 1865, descrita como crioula, com 5 anos de idade e avaliada em 500 mil réis, mas sua alforria foi passada dois anos antes, em 1/6/1863, por documento assinado pelos irmãos Dr. Félix Xavier da Cunha, Diogo Fortunato Xavier da Cunha e Francisco Xavier da Cunha, os quais declararam que aquela concessão era feita em cumprimento da vontade da falecida e "saudosa" mãe dos senhores, Maria Quitéria de Castro e Cunha, por tê-la "libertado em sua vida [...] e não deixando auto algum autêntico dessa sua vontade". ${ }^{36}$

A alforria condicional concedida na verba testamentária obrigava Ataliba a trabalhar escravizado até completar 28 anos ao filho de sua senhora, Francisco Xavier da Cunha, o que se completaria no ano de 1883. Nem no depoimento na justiça dado em 1880 ou em seu casamento no ano seguinte, consta qualquer menção a que ele continuasse escravizado, fazendo-nos supor que seu senhor o havia libertado antecipadamente. Os irmãos Xavier da Cunha, Francisco e Félix, foram promotores da fundação do Partido Liberal no Rio Grande do Sul:

Em 1863, Félix da Cunha e Silveira Martins entregaram um manifesto ao brigadeiro Manuel Luís Osório, que viria a ser o programa do Partido. Nele eram defendidas a soberania nacional, a responsabilidade dos ministros, a temporariedade do Senado, a eleição direta, a representação das minorias no Parlamento, a independência da magistratura, a liberdade individual, a emancipação da navegação de cabotagem, o serviço militar obrigatório, a descentralização administrativa e a reforma das municipalidades. Futuramente muitos destes tópicos seriam lentamente abandonados ou aprovados de forma que não alterassem as estruturas políticas e sociais. ${ }^{37}$ [grifos nossos]

Fundava-se, assim, o Partido Liberal, sob a liderança do general Osório e de Félix da Cunha. Nesse período, Félix e seu irmão Francisco compraram o jornal Mercantil, usando-o para divulgação das ideias políticas da nova agremiação. Infelizmente, tuberculoso, Félix faleceu em fevereiro de 1865, com apenas 32 anos de idade. ${ }^{38} \mathrm{Na}$ citação acima, o historiador Jonas Vargas lista as reivindicações dos liberais do período, dentre as quais grifamos duas, a eleição direta e o serviço militar obrigatório, por mostrarem como os dois pontos destacados pelo sacristão Isidoro Francisco Xavier no processo de 1880 encontravam eco na plataforma liberal, o

$36 \quad$ APERS $-1^{\circ}$ Tabelionato de Porto Alegre, livro 17, folha 199v, 7 jan. 1864.

37 VARGAS, Jonas Moreira. Entre a paróquia e a corte: uma análise da elite política do Rio Grande do Sul (1868-1889). 2007. Porto Alegre: Dissertação (Mestrado em História) - Universidade Federal do Rio Grande do Sul, PPGH, 2007. p. 56.

38 APERS - $2^{a}$ Vara de Família e Sucessão de Porto Alegre, caixa 004.1450, auto 309, 1865. 
que justificava a simpatia dos militantes-músicos da Floresta Aurora com essa agremiação político-partidária.

Analisando o caso norte-americano, Ira Berlin comenta que: "O serviço militar não era apenas uma porta pela qual os negros saíam da escravidão, mas também um acesso para a cidadania. Lutar e morrer pela União acelerou as reivindicações dos soldados negros e de todos os afro-americanos à condição de membros plenos da sociedade americana. Sua noção de habilitação aos direitos de cidadãos cresceu com o serviço militar". ${ }^{39}$ Aos efetivamente recrutados e às suas famílias e amigos predominou uma "noção de orgulho" pelas ações praticadas, mesmo que tenham custado a vida e a saúde de muitos dos envolvidos diretamente. Berlin chama a atenção para um "poder moral" que permeava as reivindicações que se esteavam em "seus serviços como trabalhadores e soldados". A contundente declaração do sacristão Isidoro, conclamando seus companheiros a irem recorrer à justiça, pois "certamente havemos de ser atendidos em nossos direitos por ela, uma vez que servimos para votantes e soldados, não obstante a nossa cor" ecoa na agenda liberal do período.

Aliás, um dos músicos daquele embate de 1880 constava listado, naquele mesmo ano, na lista geral dos cidadãos qualificados votantes da paróquia de Nossa Senhora do Rosário, da cidade de Porto Alegre. ${ }^{40}$ Trata-se do carpinteiro Teodoro Augusto Ferreira, listado com o número 173 e descrito com 28 anos de idade, solteiro, filho de Maria Ferreira, morador na rua do Riachuelo e com renda conhecida de $300 \$$ réis. Assim, os músicos da Floresta Aurora reivindicavam sua cidadania alertando para a importância do eleitorado negro e dos serviços militares historicamente prestados pela comunidade de cor, principalmente em uma província marcada por constantes embates bélicos e que saíra há poucos anos da Guerra do Paraguai. ${ }^{41}$

Como relação à expressão "não obstante a nossa cor", ela não nos permite pressupor, nem de longe, uma postura autodepreciativa, de enaltecimento das virtudes da cor branca. Tratava-se ali, a nosso ver, de uma postura crítica

39 BERLIN, op. cit., p. 303.

40 AHRS - Fundo Eleições, maço 1.

41 Considerando a questão envolvendo cidadania e serviço militar, no Brasil, sugerimos: BEATTIE, Peter M. Tributo de sangue: Exército, Honra, Raça e Nação no Brasil 1864-1945. São Paulo: Editora da USP, 2009. KRAAY, Hendrik. Em outra coisa não falavam os pardos, cabras e crioulos: o "recrutamento" de escravos na guerra da independência na Bahia. Revista Brasileira de História, São Paulo, v. 22, n. 43, p. 109-126, 2002. Idem. Política racial, estado e forças armadas na época da independência: Bahia, 1790-1850. São Paulo: Hucitec Editora, 2011. NASCIMENTO, Álvaro Pereira. Recrutamento para a Marinha brasileira. República, cor e cidadania. In: MUGGE, Miquéias H.; COMISSOLI, Adriano. (org.). Homens e armas: recrutamento militar no Brasil - Século XIX. São Leopoldo: Oikos, 2011. p. 235-256. FLORES, Giane Caroline. Sob a farda da polícia: controle social, trabalho, cor e prestígio (Porto Alegre, fins do século XIX). 2018. Dissertação (Mestrado em História) - Universidade do Vale do Rio dos Sinos, São Leopoldo, 2018. 


\section{PAULO ROBERTO STAUDT MOREIRA}

contundente à perceptível influência de critérios raciais no estabelecimento das hierarquias sociais, percebidas estas em acontecimentos muitas vezes constituídos de interações sociais banais. Demarcadores raciais que se fundamentavam em fenótipos, mas que também tomavam em consideração genealogias e proximidades e distâncias com o mundo do cativeiro. Trata-se de uma expressão de cidadania protestar contra maus-tratos movidos por preconceitos raciais. Através de ações como essas, movidas junto ao poder público, podemos perceber alguns significados presentes no universo político dessa população negra forra/livre, vivendo em uma sociedade ainda escravista.

\section{Considerações finais}

Podemos especular que o associativismo negro é habitualmente estudado em sua conexão com a oficialidade, ou seja, agremiações que funcionaram publicamente, endossadas pelo olhar público comunitário e das autoridades, registradas em órgãos públicos (como a Igreja no tempo do padroado régio, com seus regimentos e regulamentos). Mas existiram solidariedades secretas, privadas dos olhares brancos, que muito dificilmente conseguimos acessar, mas cujos vestígios nos induzem a pensar na sua realidade histórica. Nara Regina Dubois de Jesus ${ }^{42}$ menciona formas organizacionais secretas, citando como exemplo os capoeiras e manifestações afrorreligiosas, como os candomblés e batuques. No caso de Porto Alegre, existem vários registros documentais de centros afrorreligiosos, com comunidades estruturadas e com hierarquias próprias, contando com lideranças etnorreligiosas específicas. Podemos também destacar o caso do clube mina atacado pelos meganhas no $1^{\circ}$ Distrito de Porto Alegre em 1837, em plena vigência da guerra civil farroupilha (1835-1845). Uma denúncia secreta chamava a atenção das autoridades para a "casa que servia aos pretos como de escola onde aprendiam a ler e escrever, causando por isso não infundados receios dos perigos e funestas consequências que daí podiam resultar ao Brasil, como infelizmente já tem acontecido na Bahia e em outras partes, que se ressentem de ensaios semelhantes, que têm abortado". ${ }^{43}$

Os regulamentos das associações expõem os interesses e as expectativas dos membros fundadores de uma agremiação específica, mas às vezes conseguimos

\footnotetext{
Op. cit., p. 12.

43 Ver: REIS, João José; GOMES, Flávio dos Santos; CARVALHO, Marcus J. M. de. O Alufá Rufino: tráfico, escravidão e liberdade no Atlântico negro (1822-1853). São Paulo: Companhia das Letras, 2010. MOREIRA, Paulo. Manipanços, feitiçarias, alcorões: africanos muçulmanos no Brasil meridional (Porto Alegre, século XIX). História em Revista, Pelotas, v. 24, n. 2, p. 107-140, mar. 2019.
} 
acessar documentos que visibilizam esses mesmos agentes sociais em outros espaços e momentos, e com isso nos debruçamos com mais complexidade nas suas motivações e nos seus enredamentos sociais.

Considerando o acontecimento de 1880, existe neste caso, principalmente tomando as agências e discursos do sacristão Isidoro Francisco Xavier, o comportamento de uma liderança de classe, de um segmento social e racial, que toma para si a função de formatar agendas políticas, traduzindo anseios e expectativas de um coletivo específico. Muitas das demandas ali registradas eram produzidas por reivindicações políticas evidentes e até mesmo básicas, relacionadas com noções de respeito cotidiano. Se aqueles indivíduos negros se percebiam já participando efetivamente de específicas esferas de cidadania-como o serviço militar ou as eleições -, suas sensibilidades eram profundamente afetadas por sucessivos atos cotidianos de desconsideração e desacato. Esses acontecimentos habituais de desrespeito, fossem praticados por membros da própria comunidade (taberneiros, por exemplo) ou por integrantes da gestão pública (como a força policial e a justiça), exigiam reações contundentes e imediatas, sendo através da queixa judiciária, ou sendo através da efetiva ou potencial ação da ronda negra:

\begin{abstract}
Independente de sua natureza, o acontecimento se fabrica, se desloca e se realiza no vasto campo das emoções. Os modos de percepção, de apropriação dos acontecimentos pelos indivíduos não se reportam apenas à sua inteligibilidade, mas aos afetos, entre os muitos sentimentos possíveis de paixão, temor ou indiferença com os quais os atores podem reagir ao que thes acontece. Esse campo emocional, de difícil reaquisição, porque plural e lábil, quase sempre ignorado, relegado pela corporação histórica como cortina de fumaça e soma de considerações medíocres, pobre de ensinamentos, se mostra ao contrário como uma entrada privilegiada. "Podemos até adiantar que é ele que move o acontecimento e o estabelece como fenômeno histórico". ${ }^{44}$
\end{abstract}

Esperamos que este artigo contribua para percebermos que antes de 1888 não havia apenas ações individuais, mas formas de ação coletivas e associativas. Não temos o menor problema em admitir que isso já foi defendido e provado por vários pesquisadores, que se debruçaram em coletividades irmanadas por devoções afrocatólicas, em trajetórias de abolicionistas negros, em iniciativas apenas aparentemente personalistas, mas que testaram, tensionaram e modificaram os códigos legais e as jurisprudências defendendo, criando e reivindicando direitos diversos. Essas foram experiências sociais que forjaram tradições.

44 DOSSE, François. Renascimento do acontecimento. Um desafio para o historiador: entre esfinge e fênix. São Paulo: Editora Unesp, 2013. p. 145. 


\section{Abreviaturas:}

AHCMPA - Arquivo Histórico da Cúria Metropolitana de Porto Alegre

AHRS - Arquivo Histórico do Estado do Rio Grande do Sul

ANRJ - Arquivo Nacional do Rio de Janeiro

APERS - Arquivo Público do Estado do Rio Grande do Sul

CHC-SCMPA - Centro Histórico-cultural da Santa Casa de Misericórdia de Porto

Alegre

HDBN - Hemeroteca Digital da Biblioteca Nacional

MCHC - Museu da Comunicação Hipólito José da Costa

Recebido em 06/08/2019

Aprovado em 19/10/2019 